OPEN ACCESS

Edited by:

Masayasu Kojima,

Kurume University, Japan

Reviewed by:

Pei-San Tsai,

University of Colorado Boulder,

United States

Hana Zemkova,

Academy of Sciences of the Czech

Republic (ASCR), Czechia

*Correspondence:

Ishwar Parhar

ishwar.parhar@monash.edu

Specialty section:

This article was submitted to Neuroendocrine Science,

a section of the journal

Frontiers in Endocrinology

Received: 22 June 2021

Accepted: 23 August 2021

Published: 10 September 2021

Citation:

Teo CH, Phon B and Parhar I (2021)

The Role of GnlH in Biological

Rhythms and Social Behaviors.

Front. Endocrinol. 12:728862.

doi: 10.3389/fendo.2021.728862

\section{The Role of GnlH in Biological Rhythms and Social Behaviors}

\author{
Chuin Hau Teo, Brandon Phon and Ishwar Parhar* \\ Brain Research Institute, Jeffrey Cheah School of Medicine and Health Sciences, Monash University Malaysia, Bandar \\ Sunway, Selangor, Malaysia
}

Gonadotropin-inhibitory hormone $(\mathrm{Gn} \mid \mathrm{H})$ was first discovered in the Japanese quail, and peptides with a C-terminal LPXRFamide sequence, the signature protein structure defining $\mathrm{GnlH}$ orthologs, are well conserved across vertebrate species, including fish, reptiles, amphibians, avians, and mammals. In the mammalian brain, three RFamiderelated proteins (RFRP-1, RFRP-2, RFRP-3 $=\mathrm{GnIH}$ ) have been identified as orthologs to the avian $\mathrm{GnlH}$. GnlH is found primarily in the hypothalamus of all vertebrate species, while its receptors are distributed throughout the brain including the hypothalamus and the pituitary. The primary role of $\mathrm{GnlH}$ as an inhibitor of gonadotropin-releasing hormone $(\mathrm{GnRH})$ and pituitary gonadotropin release is well conserved in mammalian and nonmammalian species. Circadian rhythmicity of $\mathrm{GnlH}$, regulated by light and seasons, can influence reproductive activity, mating behavior, aggressive behavior, and feeding behavior. There is a potential link between circadian rhythms of $\mathrm{GnlH}$, anxiety-like behavior, sleep, stress, and infertility. Therefore, in this review, we highlight the functions of $\mathrm{GnlH}$ in biological rhythms, social behaviors, and reproductive and nonreproductive activities across a variety of mammalian and non-mammalian vertebrate species.

Keywords: GnIH, social behavior, circadian rhythms, reproductive rhythms, RFRP, reproductive activities

\section{INTRODUCTION}

Pituitary gonadotropins, stimulated by gonadotropin-releasing hormone ( $\mathrm{GnRH})$, did not have any known inhibitory hormone until the discovery of a novel RFamide neuropeptide [RFamide-related protein (RFRP)] in birds (1). Encoded by the $n p v f$ (neuropeptide VF) gene, RFRP dodecapeptide is also known as gonadotropin-inhibitory hormone $(\mathrm{GnIH})$ because of its inhibitory effect on $\mathrm{GnRH}$ and gonadotropin release, shown for the first time in the Japanese quail Coturnix japonica (1). In the two decades since its discovery, GnIH has been identified in several mammalian (2-5) and nonmammalian species $(4,6)$. In general, GnIH and its orthologs perform similar functions across species, which is to regulate reproduction via the inhibition of GnRH-mediated gonadotropin release.

Three different RFamide-related proteins, RFRP-1, RFRP-2, and RFRP-3, orthologous to avian $\mathrm{GnIH}$, have been identified from the mammalian brain; these proteins are cleaved from the propeptide NPVF (NPVF precursor) coded by the $n p v f$ gene (7). Among these mammalian GnIH orthologs, RFRP-1 and RFRP-3 contain the LPXRFa sequence, which is lacking in RFRP-2 (8). Subsequent studies have shown that the sequence previously considered to be the C-terminus of RFRP-2 is actually a part of the N-terminus of RFRP-3 $(3,9,10)$, which means that RFRP-1 and 
RFRP-3 are the only orthologous GnIHs present in mammalian species (ovine, bovine, rodents, and primates). RFRP-3 has been shown to inhibit the synthesis and release of mammalian gonadotropin, demonstrating similar function and structural similarity to $\mathrm{GnIH}(5,11,12)$. In this review, GnIH and RFRP3 will be used interchangeably, with RFRP-3 being used in particular when discussing the mammalian variant of the peptide.

From an evolutionary standpoint, peptides with a similar or homologous structure to $\mathrm{GnIH}$ have been isolated and identified in teleosts, birds, amphibians, reptiles, and mammalian species $(12,13)$. In each of these peptides, a similar C-terminal LPXRFamide (X = L or $\mathrm{Q}$ ) sequence is observed, indicating evolutionary conservation of the amino acid motif within mammalian and non-mammalian vertebrates (14). While this suggests that LPXRFamides share a common trait in regulating pituitary functions and inhibiting $\mathrm{GnRH}$, they have also diversified in their hypophysiotropic activities, particularly in non-mammalian vertebrates (15).

Internal factors such as sex steroids and external factors such as stress can regulate $\mathrm{GnIH}$, which in turn may positively or negatively impact reproduction. GnIH-regulated gonadotropins [luteinizing hormone (LH) and follicle-stimulating hormone (FSH)] can also have an impact on GnIH itself-LH can decrease RFRP neuronal activity during the LH surge (16).

$\mathrm{GnRH}$ neurons are directly regulated by estrogen via estrogen receptor- $\beta$ (ER- $\beta$ ) in mice (16-21), female hamster RFRP neurons express estrogen receptor- $\alpha$ (ER- $\alpha$ ) (22), and estradiol-17 $\beta$ treatment decreases c-Fos activity in enhanced green fluorescent protein (EGFP)-GnIH neurons (23) in rats. The presence of estrogen receptors on $\mathrm{GnIH}$ neurons indicates that the GnIH system may also mediate reproductive activity via participation in the negative feedback loop of estrogen-GnRH.

More recently, in vitro hypothalamic GnIH neurons have been demonstrated to express glucocorticoid receptors (24), and Son et al. (25) have identified glucocorticoid responsive elements in the promoter region of the rat $n p v f$ gene that are receptive to corticosterone as well as corticosterone-stimulated recruitment of glucocorticoid receptors. These discoveries describe a molecular mechanism for the regulation of the $\mathrm{GnIH}$ system under stress that involves direct action by glucocorticoids. Another factor that controls $\mathrm{GnIH}$ is circadian rhythmicity. The cyclic nature of reproductive rhythms (26-31) suggests $\mathrm{GnIH}$, being a reproductive molecule, changes in a seasonal and cyclic manner.

In this review, we highlight the functions of $\mathrm{GnIH}$ in reproductive rhythms, behaviors, and non-reproductive activities across a variety of mammalian and non-mammalian vertebrate species.

\section{DISTRIBUTION}

To date, very few studies have been conducted on the localization, function, and binding of RFRP-1 and RFRP-2 independently of RFRP-3. In rodents, the distribution of
RFRP-1 is highest in the hypothalamus, followed by the thalamus, midbrain, and optic nerve, with trace amounts in the hippocampus (3). GnIH peptides have been reported in the hypothalamus of various vertebrates across multiple speciesbovine, rodent, avian, amphibians, and fish (32). Distribution studies for $\mathrm{GnIH}$ are extensive and have been covered in many reviews $(14,33,34)$; as such, this paper will briefly summarize the results of those findings, with a major focus on fish, avians, and mammals.

In fish, GnIH mRNA is primarily localized in the nucleus posterioris periventricularis $(\mathrm{NPPv})$ in the hypothalamus of goldfish (4), sockeye salmon (35), Indian major carp (36), and the tilapia (37). GnIH-immunoreactive fibers have been shown in the olfactory bulb, pituitary, and spinal cord $(4,35,36)$. In the avians, $\mathrm{GnIH}$ is primarily found in the paraventricular nucleus (PVN) of the hypothalamus and GnIH fibers are seen in the median eminence and the diencephalic and mesencephalic regions $(1,12,38)$.

$\mathrm{GnIH}$ neurons in rodents are located in highest density particularly within the compact dorsal and ventral regions of the dorsomedial nucleus of the hypothalamus $(\mathrm{DMH})(22,23)$. Numerous GnIH-immunoreactive fibers project into the hypothalamic and limbic structures, the diencephalic and mesencephalic regions, and come into close apposition with GnRH neurons $(22,39)$. In ovine species like the sheep, GnIH neuronal population is disperse throughout the $\mathrm{DMH}, \mathrm{PVN}$, and the medio-basal hypothalamus (2). In particular, GnIH cell bodies are observed in high density in the $\mathrm{DMH}$, with their terminals projecting to the internal layer of the median eminence and to several midbrain regions including the diagonal band of Broca, preoptic area (POA), and the anterior pituitary (40). In general, GnIH is found in different parts of the brain depending on the species, though its presence in the hypothalamus and pituitary is common across mammals, avians, and fish (Table 1). The prominence of $\mathrm{GnIH}$ in the hypothalamus contributes to majority of its functions such as reproduction, feeding, anxiety, and social behaviour (Figure 2).

\section{RECEPTOR BINDING AND MECHANISM OF ACTION}

\subsection{Specific Binding of GnIH to GPR147}

$\mathrm{G}$ protein-coupled receptors (GPCRs) for $\mathrm{GnIH}$ were first identified by Hinuma et al. (7) where they found a cDNA that encoded a GPCR that responded to RFRP-1 and RFRP-3. The seven transmembrane receptor was named OTGT022 that corresponds to GPR147 (7). Bonini et al. (45), while investigating receptors for neuropeptide FF-amide (NPFF), a neuropeptide with a C-terminal PQRFa motif, discovered two GPCRs that interacted with NPFF, namely, NPFF1 (essentially GPR147) and NPFF2 (essentially GPR74) $(45,46)$. NPFFs bind to GPR74 with higher affinity in both COS-7 and HEK293 cell lines (45), indicating a possible difference in binding affinity between RFRP and NPFF with GPR147 and GPR74, respectively. RFRPs have about 100 times higher binding affinity for GPR147 
TABLE 1 | Distribution of GnlH, GnlH-ir fibers, and GPR147 in various central and peripheral tissues.

\begin{tabular}{|c|c|c|c|c|c|}
\hline Tissue & GnIH & GnIH-ir fibers & GPR147 & Species & References \\
\hline \multicolumn{6}{|l|}{ Central tissues } \\
\hline Amygdala & - & + & + & Mammals & $(14,29,30)$ \\
\hline Hippocampus & - & + & + & Mammals & $(14,29,30)$ \\
\hline Nucleus posterioris periventricularis & + & + & + & Fish & (30) \\
\hline Dorsomedial hypothalamus & + & + & + & Mammals & $(14,29,30)$ \\
\hline Paraventricular nucleus & + & + & + & Avian, mammals & $(14,29,30)$ \\
\hline Median eminence & - & + & + & Avian, mammals & $(14,29,30)$ \\
\hline Pituitary & + & + & + & Fish, avian, mammals & $(14,29,30)$ \\
\hline Olfactory bulb & - & + & + & Fish & (30) \\
\hline Spinal cord & + & + & + & Fish, avian, mammals & $(14,29,41)$ \\
\hline \multicolumn{6}{|l|}{ Peripheral tissues } \\
\hline Heart & + & - & + & Mammals & $(42)$ \\
\hline Gonads & + & - & + & Fish, Avian, Mammals & $(43,44)$ \\
\hline
\end{tabular}

+, regions where GnlH, GnlH-ir, or GPR147 has been found to be localized; -, regions where GnlH, GnlH-ir, or GPR147 has not been detected; GnIH, gonadotropin-inhibitory hormone.

than NPFFs, while NPFFs have about 10 times higher binding affinity to GPR74 than RFRPs (46-49).

Yin et al. (41) used a combination of $3^{\prime} / 5^{\prime}$ RACE with PCR primers based on the structure of the GPR147 from rats and cloned a cDNA encoding a $\mathrm{GnIH}$ receptor. They verified using a crude membrane fraction of COS-7 cell line transfected with the putative $\mathrm{GnIH}$ receptor cDNA that $\mathrm{GnIH}$ and $\mathrm{GnIH}$-related peptides (GnIH-RPs) bind to GPR147 with high affinity, while non-amidated $\mathrm{GnIH}(\mathrm{GnIH}-\mathrm{OH})$ fails to bind to GPR147 (41). Yin et al. (41) also used mammalian RFRP, chicken GnIH, $\mathrm{GnIH}-\mathrm{OH}$, and other neuropeptides lacking the C-terminal LPXRFa motif in competitive binding experiments to reveal that binding of GnIH to GPR147 relies on the critical LPXRFa C-terminal motif. In the competitive binding experiments, all $\mathrm{GnIH}$ orthologs successfully inhibited binding of avian $\mathrm{GnIH}$, while $\mathrm{GnIH}-\mathrm{OH}$ and the other neuropeptides without the C-terminal LPXRFa motif did not inhibit binding (41). The Scatchard plot analysis also showed that GPR147 had a single class of high-affinity binding sites $\left(\mathrm{K}_{\mathrm{d}}=0.752 \mathrm{nM}\right)$ for $\mathrm{GnIH}$ and GnIH-RPs (41). Thus, it is well documented that GnIH mainly couples with GPR147.

Localization studies have shown GPR147 in brain areas such as the hypothalamus (50), pre-optic area (51), and spinal cord (52). GPR147 is also present in GnRH neurons of fish (6), avians (43), reptiles (44), amphibians (53), mammals (50), and humans (5). Furthermore, GPR147 is present in the pituitary (43) and in gonadotrophs of various non-mammalian and mammalian vertebrates. Furthermore, the expression of GPR147 has been shown in the testes (54) and ovaries (55) of many vertebrate species. These studies suggest that $\mathrm{GnIH}$ has a significant role in reproduction.

\subsection{GnIH Mechanism of Action}

GnIH receptors (GPR147) inhibit adenylate cyclase (AC) activity by coupling to $G_{\alpha i}$ protein (7), which has been shown in COS-7 cells transfected with GPR147. A decrease in $\mathrm{G}_{\alpha i}$ mRNA levels follows RFRP exposure, suggesting that GPR147 might be coupled to $G_{\alpha i}$ (56). In another study, ovine RFRP treatment inhibited the increase in calcium levels generated by $\mathrm{GnRH}$, which is essential for LH secretion (2). On the other hand, chicken GnIH treatment of GH3 cells transfected with GPR147 did not increase inositol phosphate and cAMP production, which are the main indicators for $G_{\alpha s}$ or $G_{\alpha q}$ coupling. This indicates that GPR147 does not couple to either $G_{\alpha s}$ or $G_{\alpha q}$. Co-stimulation of GH3 cells with $\mathrm{GnIH}$ and forskolin (FSK) significantly reduced cAMP CRE-luciferase activity in GH3 cells, revealing that GPR147 mainly couples with $\mathrm{G}_{\alpha \mathrm{i}}$ to inhibit $\mathrm{GnRH}$ activity (57).

Son et al. (58) determined the GnIH/RFRP intracellular cell signaling pathway using a mouse gonadotrope (L $\beta$ T2) cell line that exhibits all the characteristics of fully differentiated gonadotropes. FSK and GnRH-induced CRE-luciferase activity is significantly reduced by the adenylate cyclase inhibitor MDL (58). As mouse RFRP inhibits GnRH-induced increase in CREluciferase activity in a similar manner, this suggests that $\mathrm{GnIH} /$ RFRP directly inhibits GnRH-induced cAMP production (58). RFRP can also inhibit GnRH-stimulated extracellular signalregulated kinase (ERK) phosphorylation elicited by $\mathrm{GnRH}$ in a mouse LBT2 cell line (58) and a mouse GnRH neuronal cell line (59). These experiments show that RFRP/GnIH specifically inhibits $\mathrm{GnRH}$ via the AC/cAMP/PKA pathway by coupling to $\mathrm{G}_{\alpha \mathrm{i}}$, preventing the activation of ERK1/2 signaling, that is important in the transcription of gonadotropins such as LH $\beta$ (Figure 1). While GnIH has also been shown to inhibit GnRHinduced increase in intracellular calcium (2), a process associated with the exocytotic release of the gonadotropins $(60,61)$ from the pituitary gland, the mechanism behind this action is yet undetermined.

\section{PHYSIOLOGICAL ROLES}

A large body of data in non-mammalian and mammalian studies suggests that $\mathrm{GnIH}$ is involved in reproduction, reproductive rhythms, reproductive behaviors, social behaviors, circadian rhythms, and other physiological roles like nociception $(47,62$, 63), learning (64), and cardiac activity (65) (Figure 2).

\subsection{Reproduction}

The involvement of $\mathrm{GnIH}$ in reproduction has been well conserved across vertebrate species even when mammalian species are administered with avian GnIH (66). There are 


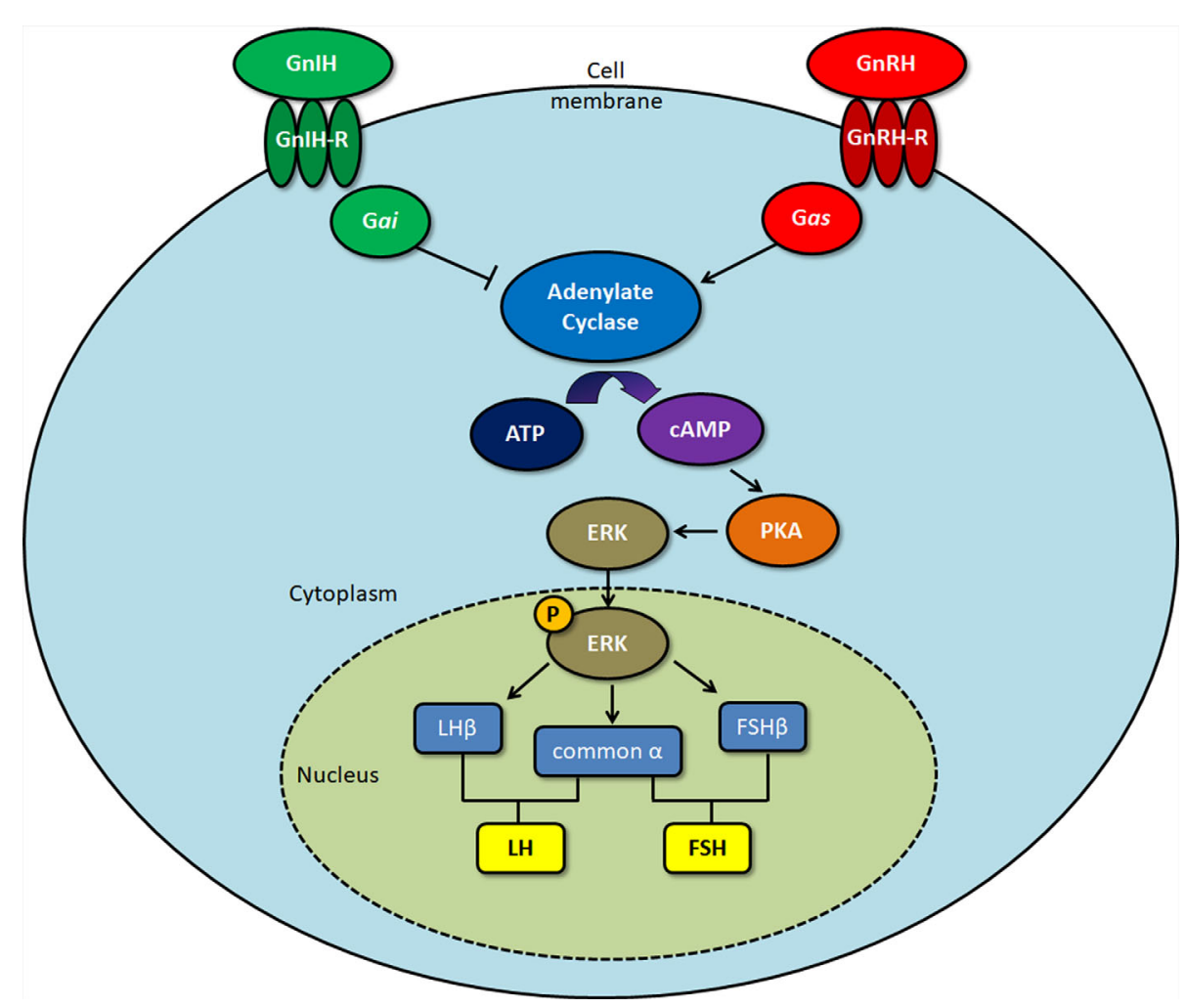

FIGURE 1 | Signaling pathway of gonadotropin-inhibitory hormone (GnIH)/RFamide-related protein (RFRP)-3 upon binding to the GPR147 GnIH receptor. Protein kinase A (PKA), extracellular signal-regulated kinase (ERK). Gonadotropin-releasing hormone (GnRH) binds to the $G n R H$ receptor, activating $G_{a s}$ protein, which induces cAMP production. Upon binding to the $\mathrm{GnlH}$ receptor, $\mathrm{G}_{a i}$ protein acts to inhibit $\mathrm{G}$ RHH-induced cAMP production, leading to a decrease in ERK activation. As phosphorylated ERK is involved in the transcription of the gonadotropin subunits $\mathrm{LH} \beta, F S H \beta$, and common $\alpha$, this ultimately results in downregulation of the gonadotropins that are formed, luteinizing hormone (LH) and follicle-stimulating hormone (FSH).

various conditions such as sex, the process of gonadectomy, pubertal status, and duration of photoperiods that can lead to different effects of $\mathrm{GnIH}$ on $\mathrm{LH} / \mathrm{FSH}$ secretion. Conflicting results have been shown across different experimental designs and animal models, which are summarized in Table 2.

The expression of RFRP-1 is different between adult female and male rats. While RFRP-1 neurons and immunoreactive fibers remain unchanged in male rats during puberty, an increase is seen in post-pubertal female rats, suggesting a role for RFRP-1 in the regulation of the estrous cycle (84). RFRP-1 injections to mice induce estradiol release in a dose-dependent manner, which stimulates increased steroidogenesis in the ovaries (85). However, proliferating cell nuclear antigen (PCNA), caspase-3, and cleaved poly (ADP-ribose) polymerase (PARP) expression are significantly reduced, suggesting that RFRP-1 directly acts to inhibit folliculogenesis in the ovary (85).

\subsection{Biological Rhythms}

\subsubsection{Reproductive Rhythms}

Fish: A clear example of reproductive rhythms in fish can be seen in the grass puffer fish, Takifugu niphobles. In particular, $\mathrm{GnIH}$ levels within the diencephalon vary, and the expression peak shifts depending on whether the fish were placed in a natural light/dark condition or in a constant dark condition (86). Melatonin has circadian expression in the diencephalon; when administered intraperitoneally to the grass puffer fish, melatonin increases the expression of $\mathrm{GnIH}$, which shows the regulation of $\mathrm{GnIH}$ by melatonin and the circadian clock (86). A recent study observed the effect of various spectra of LED lights on reproductive hormones in goldfish brain cells including $\mathrm{GnIH}$ neurons (87). In this in vitro study, goldfish brain cells were exposed to red, green, and blue LED light with white fluorescent light used as control; it was found that GnIH expression was significantly lower in the cells exposed to green and blue LED light and in groups treated with melatonin (87). Furthermore, while melatonin receptors and melatonin levels were elevated at night and decreased during the day, they were expressed at relatively higher levels in groups exposed to white fluorescent and red LED light compared to groups exposed to green and blue LED light (87). Choi et al. (87) hypothesized that circadian expression of melatonin interacted with RFRP and kisspeptin, which in turn control reproductive hormone levels that induce sexual maturation in fish.

In the European sea bass (Dicentrarchus labrax), pinealectomy on males resulted in lowered expression of $\mathrm{GnIH}$ in the mid-hindbrain (88). GnIH and $\mathrm{GnIH}$ receptor expression 


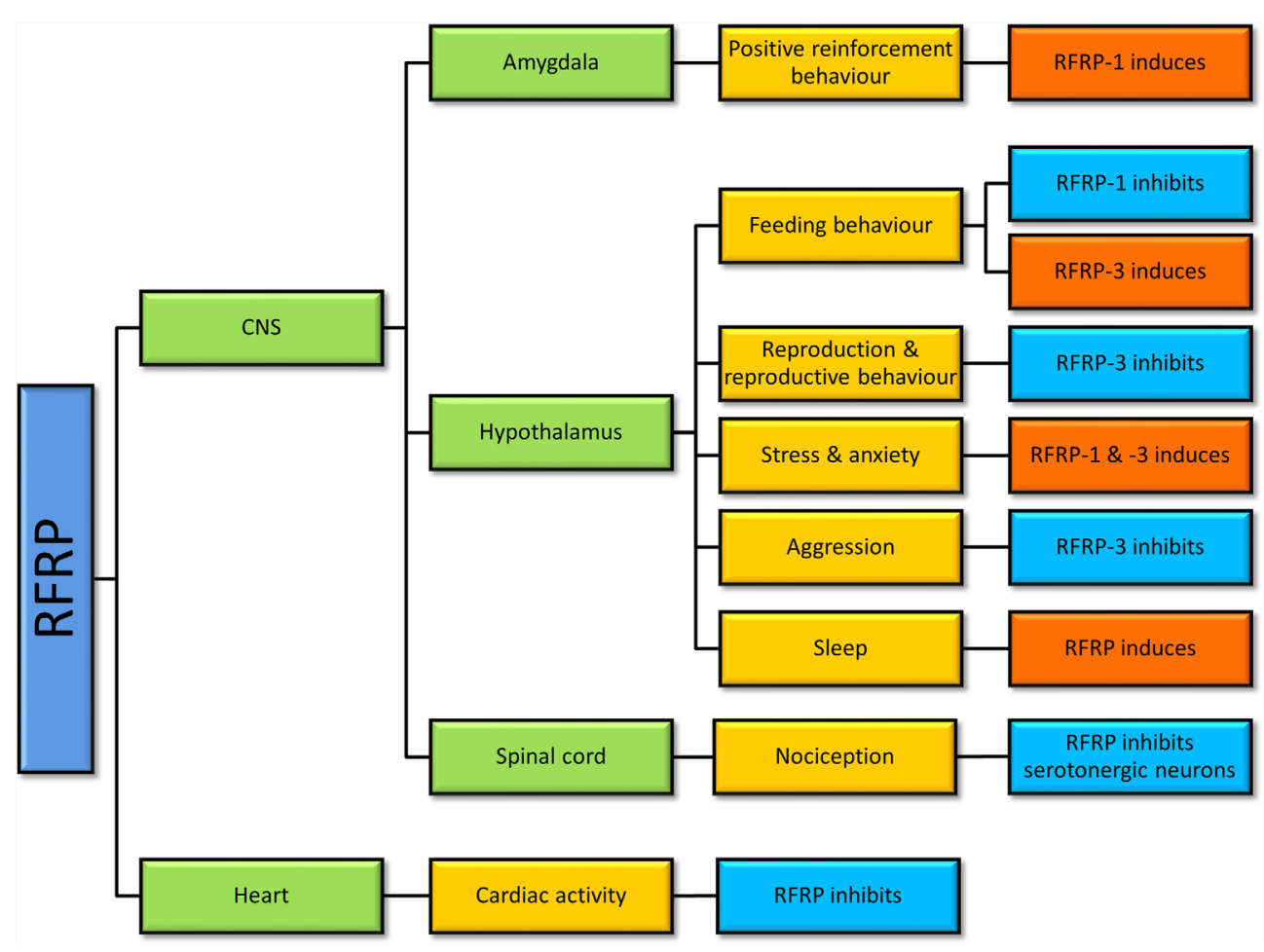

FIGURE 2 | Physiological actions of gonadotropin-inhibitory hormone (GnlH)/RFamide-related protein (RFRP) in vertebrates. Studies of RFRP in vertebrates have determined that RFRP is involved in various physiological actions centering mainly around the hypothalamus, but not limited to that region.

was also significantly reduced during reproductive seasons when compared to resting seasons (88). A long-term study on the effect of temperature on sea bass development over a period of a year demonstrated the presence of circadian rhythms in the daily expression of $\mathrm{GnIH}$ and $\mathrm{GnIH}$ receptors; at early developmental stages, $\mathrm{GnIH}$ and $\mathrm{GnIH}$ receptors were more highly expressed in the day, while more mature sea bass expressed a shift to higher nocturnal levels (88).

In the cinnamon clownfish, intraperitoneal injections of GnIH increased melatonin levels in the fish, confirming that $\mathrm{GnIH}$, besides its role in suppressing GnRH and sexual maturity of the clownfish, also affects melatonin production (89). This suggests that melatonin and $\mathrm{GnIH}$ may interact by reciprocally stimulating each other.

Avian: Photoperiod-dependent expression of GnRH and $\mathrm{GnIH}$ has been shown to regulate seasonal reproduction in the Eurasian tree sparrow. GnIH mRNA and GnIH-immunoreactive neurons increased significantly during the non-breeding season, and exposure to short days (SDs) induced higher GnIH expression compared to long day (LD) exposure, a change that happened regardless of the sampling month (90). In another study, sparrows were entrained to resonate with light-dark cycles, where a constant 6-h light phase was combined with a dark phase that served to vary the period of the light-dark cycles by 12 -h increments (91). It was found that specific increments were interpreted by the birds' circadian system as SD or LD. Resonance cycles that were read as LD would see testicular growth and reduction of $\mathrm{GnIH}$, while resonance cycles read as SD would see significant increase in GnIH expression (91). This suggests the presence of an endogenous circadian rhythm regulating photoperiodic expression of $\mathrm{GnIH}$. In other words, constant $6 \mathrm{~h}$ of light meant that the resonance cycle was read as $\mathrm{SD}$ or LD depending on whether the light was present on the photoinducible or non-photoinducible phase of the endogenous circadian cycle (91).

Mammals: Mason et al. (92) found that Syrian male hamsters that were exposed to SD photoperiods exhibited decreased $\mathrm{GnIH}$ immunoreactivity and mRNA expression in comparison to those exposed to LD photoperiods. DMH containing GnIH neurons may serve as a mediator for melatonin action to control gonadotropic release (93). Conversely, since the suprachiasmatic nucleus (SCN) itself is a major target for melatonin action (94), its projections to GnIH neurons in the DMH may be another possible pathway of GnIH regulation through a photoperiod-related circadian system. Ubuka et al. (95) showed lower GnIH mRNA expression in Siberian hamsters exposed to SD photoperiods compared to hamsters exposed to LD photoperiods. While GnIH has inhibitory effect in mammalian species such as rodents and humans (66), it can play a different role in seasonal reproduction. Elevated GnIH expression in LD breeders such as hamsters (96) appears to have a stimulatory effect on the reproductive axis, increasing the secretion of $\mathrm{LH}(77,79)$. Increased $\mathrm{GnIH}$ expression during $\mathrm{LD}$ photoperiods is conserved across multiple mammalian species, as SD breeders such as sheep (97) and goats 
TABLE 2 | Summary of in vivo effects of GnIH/RFRP-3 injection on LH and FSH secretion.

\begin{tabular}{|c|c|c|c|c|}
\hline Species & Condition & Injection & Effect & Reference \\
\hline Tilapia & Female, adult & $\mathbb{I P}$ & Increases $\mathrm{LH}$ and $\mathrm{FSH}$ release & $(37)$ \\
\hline $\begin{array}{l}\text { Sea } \\
\text { bass }\end{array}$ & Female, adult & ICV & Decrease in plasma LH level & $(67)$ \\
\hline Goldfish & Female and male, adult & $\mathrm{IP}$ & $\begin{array}{l}\text { Increase in } \mathrm{LH} \beta \text { and } \mathrm{FSH} \beta \text { mRNA during early to late gonadal } \\
\text { recrudescence, reduced serum } \mathrm{LH} \text { at early to mid- } \\
\text { recrudescence }\end{array}$ & (68) \\
\hline Sparrow & Female, adult & ICV & Decrease in plasma LH level & (69) \\
\hline Quail & Male, adult & IV & Decrease in LH $\beta$, FSH $\beta$ mRNA expression and serum LH level & (70) \\
\hline Rat & Female, adult, OVX & IV & Gradual decrease in plasma LH level & (71) \\
\hline Rat & Female, adult, OVX & $\begin{array}{l}\text { Acute } \\
\text { ICV }\end{array}$ & $\begin{array}{l}\text { No significant suppressive effect on the mean concentration and } \\
\text { pulsatile secretion of LH }\end{array}$ & (71) \\
\hline Rat & Female, adult, OVX, low dose of estradiol & $\begin{array}{l}\text { Acute } \\
\text { ICV }\end{array}$ & $\begin{array}{l}\text { No significant suppressive effect on the mean concentration and } \\
\text { pulsatile secretion of LH }\end{array}$ & $(72)$ \\
\hline Rat & Female, adult, OVX, high dose of estradiol & $\begin{array}{l}\text { Chronic } \\
\text { ICV }\end{array}$ & Slight but insignificant decrease in LH concentration & $(72)$ \\
\hline Rat & Female, adult, GNX & $\begin{array}{l}\text { Acute } \\
\text { ICV }\end{array}$ & $\begin{array}{l}\text { Decrease in circulating } \mathrm{LH} \text { level but no changes to the } \\
\text { circulating FSH level }\end{array}$ & $(73)$ \\
\hline Rat & Male, adult, GNX and Intact & $\begin{array}{l}\text { Acute } \\
\text { ICV }\end{array}$ & Decrease in circulating LH and FSH level & (73) \\
\hline Rat & Male, adult, GNX & IV & Moderate decrease in circulating LH and FSH level & (73) \\
\hline Mouse & $\begin{array}{l}\text { Prepubescent, female, intact; prepubescent, female, OVX, E2 } \\
\text { replacement; Adult, female, OVX; Adult, female, OVX, E2 } \\
\text { replacement }\end{array}$ & $\begin{array}{l}\text { Acute } \\
\text { ICV }\end{array}$ & $\begin{array}{l}\text { Decrease in LH concentration with no changes to FSH } \\
\text { concentration }\end{array}$ & $(74)$ \\
\hline Mouse & Prepubescent, female, OVX & $\begin{array}{l}\text { Acute } \\
\text { ICV }\end{array}$ & No changes in LH concentration & $(74)$ \\
\hline Mouse & Male, adult, GNX and intact & $\begin{array}{l}\text { Acute } \\
\text { ICV }\end{array}$ & Stimulates secretion of LH & $(75)$ \\
\hline Mouse & Female, adult, E2-negative feedback conditions & $\begin{array}{l}\text { Acute } \\
\text { ICV }\end{array}$ & No effect on LH secretion & $(75)$ \\
\hline Mouse & Female, adult, preovulatory-like surge & $\begin{array}{l}\text { Acute } \\
\text { ICV }\end{array}$ & Decrease in LH secretion & $(75)$ \\
\hline Mouse & Adult, intact, male or female, diestrus or proestrus & $\mathbb{I P}$ & No changes in LH concentration & (75) \\
\hline Bovine & Male, 5 months old, castrated & IV & $\begin{array}{l}\text { Decrease in LH pulse frequency with no changes to the } \\
\text { concentration }\end{array}$ & $(76)$ \\
\hline $\begin{array}{l}\text { Syrian } \\
\text { hamsters }\end{array}$ & Male, adult, LP and SP & $\begin{array}{l}\text { Acute } \\
\text { ICV }\end{array}$ & Increase in plasma LH and FSH levels & $(77)$ \\
\hline $\begin{array}{l}\text { syrian } \\
\text { hamsters }\end{array}$ & Female, adult, OVX, LP & $\begin{array}{l}\text { Acute } \\
\text { ICV }\end{array}$ & No changes in LH concentration & $(77)$ \\
\hline $\begin{array}{l}\text { syrian } \\
\text { hamsters }\end{array}$ & Male, adult & $\mathrm{IP}$ & Insignificant inhibition of basal LH levels & $(78)$ \\
\hline $\begin{array}{l}\text { syrian } \\
\text { hamsters }\end{array}$ & Female, adult, LP & $\begin{array}{l}\text { Acute } \\
\text { ICV }\end{array}$ & Decrease in basal LH concentration on the day of proestrus & (79) \\
\hline $\begin{array}{l}\text { syrian } \\
\text { hamsters }\end{array}$ & Female, adult, SP & $\begin{array}{l}\text { Acute } \\
\text { ICV }\end{array}$ & No effect on the basal LH concentration & (79) \\
\hline $\begin{array}{l}\text { syrian } \\
\text { hamsters }\end{array}$ & Female, adult LP & $\begin{array}{l}\text { Chronic } \\
\text { ICV }\end{array}$ & Decrease in LH concentration & (79) \\
\hline $\begin{array}{l}\text { syrian } \\
\text { hamsters }\end{array}$ & Female, adult, SP & $\begin{array}{l}\text { Chronic } \\
\text { ICV }\end{array}$ & Increase in LH concentration & (79) \\
\hline $\begin{array}{l}\text { LVG } \\
\text { hamsters }\end{array}$ & Female, adult, OVX & $\begin{array}{l}\text { Acute } \\
\text { ICV and } \\
\text { IP }\end{array}$ & Decrease in LH concentration & $(22)$ \\
\hline Ovine & Female, adult OVX & IV & Decrease in LH pulse amplitude but no effect on FSH secretion & $(2)$ \\
\hline Ovine & Intact; OVX, estrogen induced LH surge & IV & Decrease in pulse amplitude as well as concentration & (80) \\
\hline Ovine & $\begin{array}{l}\text { Female, adult, OVX, estrogen-induced LH surge; Female, adult, } \\
\text { Intact, acyclic }\end{array}$ & IV & No changes in LH secretion or plasma LH concentration & (81) \\
\hline Mare & Intact, mature, breeding season & IV & $\begin{array}{l}\text { No changes to the LH pulse amplitude, frequency, and } \\
\text { concentration }\end{array}$ & $(82)$ \\
\hline Human & Female, adult, postmenopause & IV & Significant decrease in LH secretion & (83) \\
\hline Human & Male, adult & IV & No changes in LH secretion & (83) \\
\hline
\end{tabular}

GnlH, gonadotropin-inhibitory hormone; RFRP, RFamide-related protein; LH, luteinizing hormone; FSH, follicle-stimulating hormone; OVX, ovariectomized; GNX, gonadectomized; $I V$, intravenous injection; ICV, intracerebroventricular injection; IP, intraperitoneal injection; LP, long photoperiod; SP, short photoperiod. 
also exhibit elevated GnIH during LD (98). As GnIH plays an inhibitory role in SD breeders (97), this shows that while photoperiod-dependant expression of $\mathrm{GnIH}$ is conserved, its regulatory effect downstream has evolved differently to induce reproductive axis stimulation in $\mathrm{LD}$ breeders and inhibition in SD breeders.

\subsubsection{Feeding Rhythms}

Avian: Intracerebroventricular (ICV) injection of $\mathrm{GnIH}$ into Peking duck resulted in a decrease in the plasma $\mathrm{LH}$ concentration and an increase in the food intake in Peking duck $(80,99)$. Feeding behaviors were also regulated by orexigenic peptides in the hypothalamus. Neuropeptide Y (NPY) is an orixegenic peptide produced by appetiteregulating cells and is known to stimulate food intake while pro-opiomelanocortin (POMC) is a precursor protein that gives rise to peptide derivatives that are associated with satiety (100102). Red-headed buntings demonstrate a seasonal increase in cell optical density in NPY neurons in the DMH (103). As NPY fibers have been shown to be structurally associated with $\mathrm{GnIH}$ neurons in the Indian weaver bird (104), any change in NPY may in turn affect $\mathrm{GnIH}$ expression. An example may be found in a study where adult male Albert's Towhees songbirds were food restricted during the photo-induced reproductive development phase (105). A 4-week food restriction significantly increased NPY cell number and, at the same time, decreased GnIH perikarya area (105). The decrease in $\mathrm{GnIH}$ perikarya area coincided with a decrease in plasma LH (105), suggesting that the heightened activity of the NPY system increased secretion of $\mathrm{GnIH}$ and, subsequently, inhibition of LH. In chickens (Gallus gallus), ICV injections of GnIH elevates food intake and increases neuronal activity in the lateral hypothalamic area, along with an increase in melanin-concentrating hormone and NPY expression and a decrease in POMC expression (102). In contrast to appetite stimulation by GnIH, ICV injection of RFRP-1 in chicks reduces food and water intake (106).

Mammals: Studies on the effect of RFRP-3 infusion in mammals, particularly in mice and sheep, also saw an increase in food intake that was consistent with the results observed in birds (80). The study by Clarke et al. (80) observed the role of RFRP-3 in acting as a switch for preference between feeding and reproductive activity in sheep and rats. The clear opposition between feeding and reproductive function appears to suggest that high levels of RFRP-3 activity favors feeding over reproduction. It is possible that seasonal breeders such as sheep may exhibit reduced feeding behavior during mating seasons due to RFRP-3. On the other hand, injection of RFRP1 into the central nucleus of the rat amygdala caused a decrease in food intake (107). As an NPFF receptor selective antagonist eliminated the effect in that same study, this demonstrated that the reduction in food intake was due to a receptor-linked effect in the amygdala (107).

Since feeding can be rhythmic in nature and is associated with $\mathrm{GnIH}$ regulation $(80,102)$ (Figure 2 ), the circadian nature of $\mathrm{GnIH}$ in the hypothalamus needs further investigation. Furthermore, as RFRP-1 inhibits appetite in contrast to RFRP- 3's stimulation of feeding behavior $(80,99,106,107)$, further differences in their other physiological activities may exist.

\subsection{Reproductive Behavior}

Fish: Although GnIH has been shown to play a role in reproductive function in fish (88), its influence on fish mating behavior remains unclear. While a recent study has demonstrated that the Nile tilapia experiences upregulation of $\mathrm{GnIH}$ due to defeat in territorial fights (108), the role of $\mathrm{GnIH}$ in reproductive behavior such as courting and brooding is yet unknown.

Avians: GnIH is directly responsible for the regulation of mating behavior in avians. In birds, GnIH neurons extend their projections to the periaqueductal central gray (PAG) and POA, signifying their possible role in the regulation of socio-sexual behaviors (109). Central administration of $\mathrm{GnIH}$ inhibits copulation in white-crowned sparrows (69). When infused directly into the brain, $\mathrm{GnIH}$ binds specifically to areas in the diencephalon and the midbrain where cGnRH-IIimmunoreactive neurons reside (69). Since GPR147 is expressed in GnRH-II neurons, it can be speculated that $\mathrm{GnIH}$ suppresses sexual behaviors in birds by suppressing the activity of GnRH-II neurons (110). Silencing the GnIH-encoding npvf gene using RNA interference reduces the rest-time and increases spontaneous production of complex vocalizations and agonistic vocalizations in male and female white-crowned sparrows, which are part of mating behavior (111). Heightened vocalization (song production) in male birds in response to novel male songs is associated with an increase in locomotor activity, which suggests a greater degree of central nervous system (CNS) arousal when $\mathrm{GnIH}$ is inhibited (111). Furthermore, the activity of the male birds is positively correlated to the numbers of GnRH-I and GnRH-II neurons, which are in close proximity to GnIHimmunoreactive neuronal fiber terminals. This provides further evidence of inhibition of sexual arousal in white-crowned sparrows through the decrease in GnRH-I and GnRH-II neuronal activities (111). The intense RFRP-immunoreactive fiber density in the ventral tegmental area (VTA) of the female sparrows also suggests that the inhibitory role for $\mathrm{GnIH}$ in arousal of the CNS is not sex-limited (111).

Mammals: ICV injections of RFRP-3 induced a decrease in plasma LH and a significant inhibition of sexual behavior (39). Female Syrian hamsters treated with RFRP-3 show decreased sexual motivation and vaginal scent marking but had no effect on copulatory behaviors. An increased expression of c-Fos was induced by RFRP-3 in the medial POA, bed nucleus of the stria terminalis, and the medial amygdala, all of which are part of the circuitry for female sexual behavior (112). Chronic immobilization stress-induced elevation of $\mathrm{GnIH}$ in rats decreases sexual behavior (42), pregnancy rate, and embryo resorption. These negative reproductive effects can be effectively reversed by silencing RFRP-3 using sh-RNA during stress (42). The effect can also be replicated in males, as a decrease in male sexual behavior in rats was reported upon central administration of RFRP (39). 


\section{SOCIAL BEHAVIOR}

\subsection{Aggression}

Avians: While there is no study directly linking $\mathrm{GnIH}$ to aggression in piscine species, $\mathrm{GnIH}$ is known to influence aggressive behavior in birds. Central administration of $\mathrm{GnIH}$ into male quails significantly inhibits their aggressive behavior, and GnIH RNA interference significantly increases aggression in quails (113).

Mammals: In mice, RFRP-3 neurons project to neural loci regulating aggression in addition to neuroendocrine cells controlling the production of testosterone (114). Aggressive encounters between male mice reduce RFRP/c-Fos colocalization in anteroventral periventricular kisspeptin neurons (114). As RFRP acts as a negative regulator of the reproductive axis in mice by inhibiting GnRH, lowered RFRP-3 activity results in increased reproductive axis function, which facilitates an increase in testosterone and aggressive behavior (114). Furthermore, it has been shown that consumption of a large amount of soya bean leads to the suppression of $\mathrm{GnIH}$ and reduces aromatase activity, which is responsible for converting testosterone into neuroestrogen, leading to increased aggression in mice (115).

\subsection{Stress and Anxiety}

It is known that dysfunction of the hypothalamic-pituitaryadrenal (HPA) axis dysregulates the serotonergic system (116). $\mathrm{GnIH}$ is closely linked to the HPA axis since $\mathrm{GnIH}$ neurons express glucocorticoid receptors (117), and in vitro experiments show that glucocorticoids stimulate GnIH mRNA expression (24). Stress can lead to anxiety through GnIH's action on the serotonergic system.

Fish: In the cinnamon clownfish, cortisol treatment simulated an increase in $\mathrm{GnIH}$ mRNA but decreased $\mathrm{GnRH}$ as well as lowered circulating levels of LH and FSH (118), which suggests that glucocorticoids directly increase $\mathrm{GnIH}$ expression. In addition, a recent experiment on the male Nile tilapia showed that acute stress inflicted by social defeat increased GnIH mRNA levels in the NPPv and hypothalamus, as well as GPR147 mRNA in the pituitary. However, corticotropin-releasing hormone $(\mathrm{CRH})$ and adrenocorticotropic hormone (ACTH) were not elevated, which suggests that GnIH may be directly affected by glucocorticoid signaling without an increase in $\mathrm{CRH}$ and ACTH levels (108).

Avians: Capture-handling was used to examine the role of stress in manipulating the number of GnIH neurons in the hypothalamus of adult male and female house sparrows (119). More GnIH-positive neurons were seen in the fall as opposed to during the spring, where it is the start of the breeding season. A significant increase in GnIH-positive neurons was detected in stressed birds during the spring compared to those during the fall season (119). These observations suggest that the regulation of $\mathrm{GnIH}$ by stress changes over the annual reproduction cycle (119). Whether the regulation of GnIH during stress is through glucocorticoid receptors expressed in $\mathrm{GnIH}$ neurons or indirectly through other neuropeptides remains unknown.
Mammals: Administration of RFRP-1 induces ACTH and oxytocin release in rats, facilitating an anxiogenic effect. The same effect is observed with RFRP-3, suggesting a similar function for both RFamide peptides (120). These anxiogenic effects of RFRP-1 and RFRP-3 are in stark contrast with the antidepressive effects of RFRP-1 reported in a mouse forced swim test (121). Selective serotonin reuptake inhibitor (SSRI) citalopram, an antidepressant, increases GnIH neuronal numbers in the DMH and fiber projections to the POA (122). As these brain regions are involved in reproduction, there are clear links between $\mathrm{GnIH}$, the reproductive axis, and the serotonergic system (122).

In adult rodents, immobilization stress or treatment with glucocorticoid receptor agonist, dexamethasone, increases RFRP-3 protein and inhibits hypothalamic-pituitary-gonadal (HPG) activity $(117,123)$. On the other hand, adrenalectomy blocks the increase in RFRP-3 expression brought about by stress. Stress exposure increases c-Fos expression in $\mathrm{GnIH}$ neurons of the $\mathrm{DMH}$, and direct administration of RFRP-3 induces anxiety-like behavior in rats (120). More recently, social isolation in rats has been shown to disrupt the expression of circadian locomotor output cycles kaput (CLOCK) protein and beta-catenin, a protein known to control the circadian system and implicated in social isolation-induced depression (124). Furthermore, responsiveness of GnIH neurons to serotonin differs in relation to beta-catenin expression levels (125). Thus, chronic stress-induced RFRP-3 expression may disrupt circadian rhythmicity via beta-catenin and the serotonergic system (Figure 3). Under chronic stress, clock genes may experience disruption (124), inducing an increase in beta-catenin while lowering neuronal activity (125). Beta-catenin is a vital part of the Wnt signaling pathway-activation of this pathway elevates phospholipase-D1 (126), which is connected with elevated inositol trisphosphate and calcium release (127, 128). This could leave the cell more sensitive to acute stress. Hypothalamic RFRP-3 cells express glucocorticoid receptors $(117,119)$, and glucocorticoid response elements are present in the promoter region of the rat RFRP-3 gene (24). This could contribute, in part, to the mechanism of regulation of $\mathrm{GnIH}$ under stressful situations.

\section{SLEEP}

Fish: Circadian influence on GnIH has been suggested for sleep. The npvf gene encoding for RFRP-1 and RFRP-3 has been associated with sleep in larval zebrafish. Overexpression of RFRP via a heat shock-inducible promoter drastically increases sleep duration for the zebrafish (129). However, when RFRP is overexpressed in the middle of the day, the sleeping pattern of the night is unchanged, suggesting that there are other circadian components that prevent sleep from occurring early (129).

In larval zebrafish, increasing the expression of either RFRP-1 or RFRP-3 via a transgene reduced locomotor activity but did not increase sleep, while overexpression of RFRP-2 significantly reduced locomotor activity and increased sleep (129). 


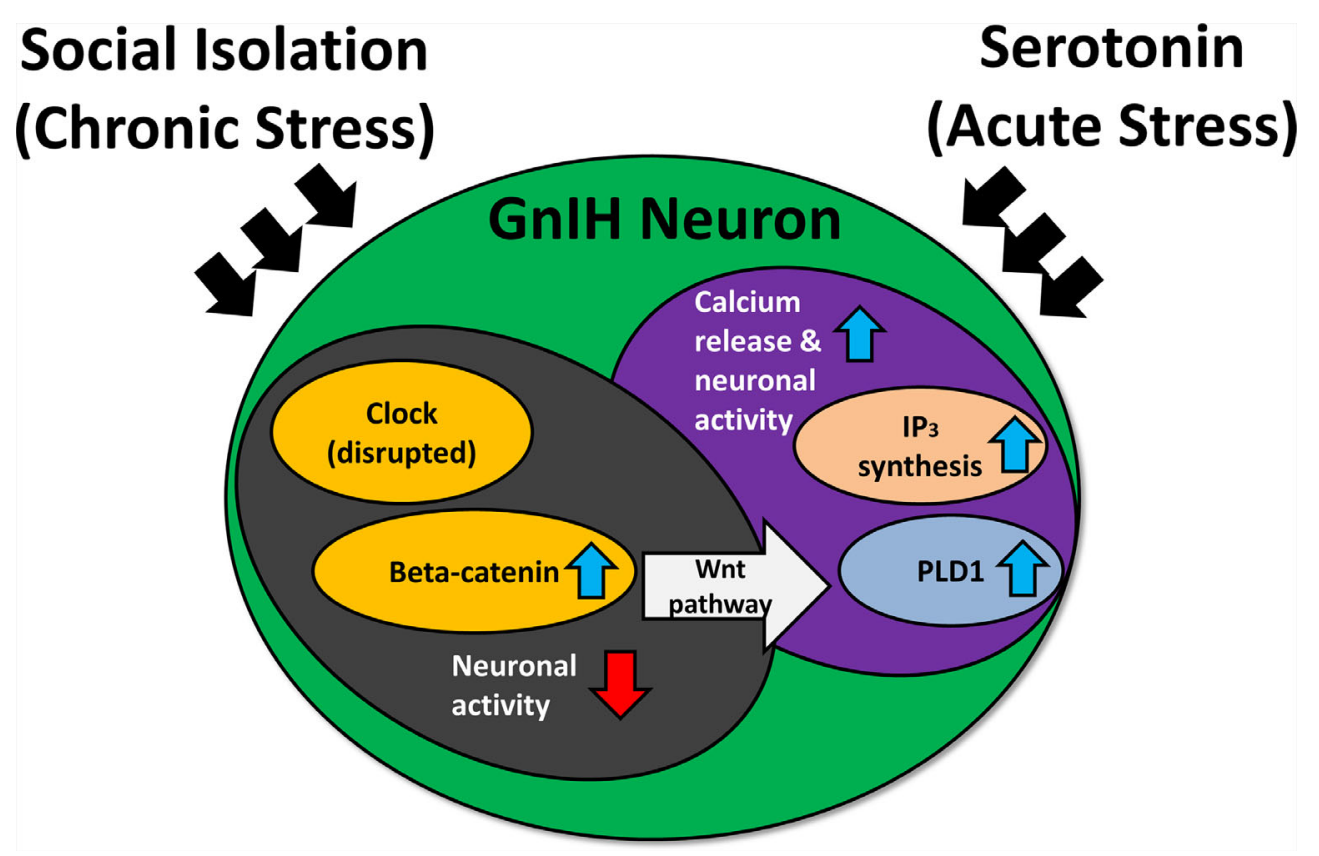

FIGURE 3 | The effect of social isolation and serotonin on CLOCK expression and neuronal activity of gonadotropin-inhibitory hormone $(G n \mid H)$ neurons. IP 3 , inositol trisphosphate; PLD1, phospholipase D1. Blue arrows indicate an increase, while red arrows indicate a decrease. Chronic stress may disrupt the expression of clock genes, inducing an increase in beta-catenin while lowering neuronal activity. The heightened levels of beta-catenin activate the Wnt pathway, which can upregulate PLD1 levels. This results in increased IP 3 production, triggering a heightened calcium response under acute stress and subsequently elevating neuronal activity.

However, the greatest impact on inducing sleep was observed with the overexpression of a combination of any two of the three RFRPs, demonstrating results similar to those of the wild type (129). Furthermore, stimulation of $\mathrm{GnIH}$ neurons produced activity levels similar to that normally observed at night and suppressed neuronal activity throughout the brain. Lastly, suppression of $\mathrm{GnIH}$ neurons also promoted wakefulness in the larvae (129).

The control of sleep by $\mathrm{GnIH}$ functions through the serotonergic raphe nuclei, since $\mathrm{GnIH}$ neurons are densely innervated by serotonergic projections from the raphe nuclei in zebrafish larvae (130). Optogenetic stimulation of RFRP neurons activated serotonergic neurons in the inferior raphe, and ablations of the serotonergic neurons of the raphe nuclei caused sleep time to remain unchanged even when $\mathrm{GnIH}$ neurons were stimulated (130). Larval zebrafish with intact raphe nuclei continued to exhibit the increased sleep time observed in the previous study (129), which suggests that $\mathrm{GnIH}$ acts upstream of serotonin to modulate sleep levels and wakefulness (130).

\section{CONCLUSION}

GnIH has been isolated and sequenced in a wide range of mammalian and non-mammalian vertebrate species. RFRP-1, RFRP-2, and RFRP-3 in the mammalian brain have been identified as orthologous to the avian $\mathrm{GnIH}$. In the brain, the hypothalamus is the main region where $\mathrm{GnIH}$ neurons are located in all vertebrate species. However, GnIH neurons are also located outside the hypothalamus in some species. GnIH binds to its GPCR, GPR147, which has a widespread distribution in the brain including $\mathrm{GnRH}$ neurons. GnIH regulates reproduction by inhibiting GnRH and pituitary LH and FSH levels. In addition, in most vertebrate species, GnIH also regulates aggression, sleep, mating behavior, anxiety-like behavior, feeding behavior, non-reproductive social behavior, as well as stress-related infertility. Photoperioddependent fluctuation in GnIH has an important role in the circadian biology of reproduction. The majority of the published studies focus on RFRP-3 and its avian ortholog GnIH. On the other hand, functions of RFRP-1 have been less explored. As there are indications of possible functional dissimilarities between RFRP-1 and RFRP-3, elucidating the functions of RFRP-1 can be a promising avenue for future studies.

\section{AUTHOR CONTRIBUTIONS}

TC, BP, and IP wrote the manuscript. All authors contributed to the article and approved the submitted version.

\section{ACKNOWLEDGMENTS}

We thank the BRIMS platform, the Jeffrey Cheah School of Medicine and Health Sciences, and Monash University Malaysia for providing us with the scholarship and infrastructure support that have been of great help in completing this review. 


\section{REFERENCES}

1. Tsutsui K, Saigoh E, Ukena K, Teranishi H, Fujisawa Y, Kikuchi M, et al. A Novel Avian Hypothalamic Peptide Inhibiting Gonadotropin Release. Biochem Biophys Res Commun (2000) 275:661-7. doi: 10.1006/ bbrc.2000.3350

2. Clarke IJ, Sari IP, Qi Y, Smith JT, Parkington HC, Ubuka T, et al. Potent Action of RFamide-Related Peptide-3 on Pituitary Gonadotropes Indicative of a Hypophysiotropic Role in the Negative Regulation of Gonadotropin Secretion. Endocrinology (2008) 149(11):5811-21. doi: 10.1210/en.2008-0575

3. Fukusumi S, Habata Y, Yoshida H, Iijima N, Kawamata Y, Hosoya M, et al. Characteristics and Distribution of Endogenous RFamide-Related Peptide1. Biochim Biophys Acta (BBA) Mol Cell Res (2001) 1540(3):221-32. doi: 10.1016/S0167-4889(01)00135-5

4. Sawada K, Ukena K, Satake H, Iwakoshi E, Minakata H, Tsutsui K. Novel Fish Hypothalamic Neuropeptide: Cloning of a cDNA Encoding the Precursor Polypeptide and Identification and Localization of the Mature Peptide. Eur J Biochem (2002) 269(24):6000-8. doi: 10.1046/j.14321033.2002.03351.x

5. Ubuka T, Morgan K, Pawson AJ, Osugi T, Chowdhury VS, Minakata H, et al. Identification of Human GnIH Homologs, RFRP-1 and RFRP-3, and the Cognate Receptor, GPR147 in the Human Hypothalamic Pituitary Axis. PloS One (2009) 4(12):e8400. doi: 10.1371/journal.pone.0008400

6. Zhang Y, Li S, Liu Y, Lu D, Chen H, Huang X, et al. Structural Diversity of the GnIH/GnIH Receptor System in Teleost: Its Involvement in Early Development and the Negative Control of LH Release. Peptides (2010) 31:1034-43. doi: 10.1016/j.peptides.2010.03.003

7. Hinuma S, Shintani Y, Fukusumi S, Iijima N, Matsumoto Y, Hosoya M, et al. New Neuropeptides Containing Carboxy-Terminal RFamide and Their Receptor in Mammals. Nat Cell Biol (2000) 2(10):703-8. doi: 10.1038/35036326

8. Tsutsui K, Bentley GE, Kriegsfeld LJ, Osugi T, Seong JY, Vaudry H. Discovery and Evolutionary History of Gonadotrophin-Inhibitory Hormone and Kisspeptin: New Key Neuropeptides Controlling Reproduction. J Neuroendocrinol (2010) 22(7):716-27. doi: 10.1111/j. 1365-2826.2010.02018.x

9. Fukusumi S, Yoshida H, Fujii R, Maruyama M, Komatsu H, Habata Y, et al. A New Peptidic Ligand and its Receptor Regulating Adrenal Function in Rats. J Biol Chem (2003) 278:46387-95. doi: 10.1074/jbc.M305270200

10. Ukena K, Tsutsui K. A New Member of the Hypothalamic RF-Amide Peptide Family, LPXRF-Amide Peptides: Structure, Localization, and Function. Mass Spectrom Rev (2004) 24(4):469-86. doi: 10.1002/mas.20031

11. Ubuka T, Kim S, Huang Y-C, Reid J, Jiang J, Osugi T, et al. GonadotropinInhibitory Hormone Neurons Interact Directly With GonadotropinReleasing Hormone-I and-II Neurons in European Starling Brain. Endocrinology (2008) 149(1):268-78. doi: 10.1210/en.2007-0983

12. Ukena K, Ubuka T, Tsutsui K. Distribution of a Novel Avian GonadotropinInhibitory Hormone in the Quail Brain. Cell Tissue Res (2003) 312(1):73-9. doi: 10.1007/s00441-003-0700-x

13. Sawada K, Ukena K, Satake H, Iwakoshi E, Minakata H, Tsutsui K. Novel Fish Hypothalamic Peptide. Eur J Biochem (2002) 269:6000-8. doi: 10.1046/ j.1432-1033.2002.03351.x

14. Tsutsui K, Ubuka T, Bentley GE, Kriegsfeld LJ. Gonadotropin-Inhibitory Hormone (GnIH): Discovery, Progress and Prospect. Gen Comp Endocrinol (2012) 177(3):305-14. doi: 10.1016/j.ygcen.2012.02.013

15. Tsutsui K, Osugi T. Evolutionary Origin and Divergence of GnIH and Its Homologous Peptides. Gen Comp Endocrinol (2009) 161(1):30-3. doi: 10.1016/j.ygcen.2008.10.002

16. Gibson EM, Humber SA, Jain S, Williams WP3rd, Zhao S, Bentley GE, et al. Alterations in RFamide-Related Peptide Expression Are Coordinated With the Preovulatory Luteinizing Hormone Surge. Endocrinology (2008) 149 (10):4958-69. doi: 10.1210/en.2008-0316

17. Sharifi N, Reuss AE, Wray S. Prenatal LHRH Neurons in Nasal Explant Cultures Express Estrogen Receptor $\beta$ Transcript. Endocrinology (2002) 143 (7):2503-7. doi: 10.1210/endo.143.7.8897

18. Hrabovszky E, Steinhauser AR, Barabás K, Shughrue PJ, Petersen SL, Merchenthaler IN, et al. Estrogen Receptor- $\beta$ Immunoreactivity in Luteinizing Hormone-Releasing Hormone Neurons of the Rat Brain. Endocrinology (2001) 142(7):3261-4. doi: 10.1210/endo.142.7.8176
19. Hrabovszky E, Shughrue PJ, Merchenthaler IN, Hajszán T, Carpenter CD, Liposits Z, et al. Detection of Estrogen Receptor- $\beta$ Messenger Ribonucleic Acid and 125I-Estrogen Binding Sites in Luteinizing Hormone-Releasing Hormone Neurons of the Rat Brain. Endocrinology (2000) 141(9):3506-9. doi: 10.1210/endo.141.9.7788

20. Petersen SL, Ottem EN, Carpenter CD. Direct and Indirect Regulation of Gonadotropin-Releasing Hormone Neurons by Estradiol. Biol Reprod (2003) 69(6):1771-8. doi: 10.1095/biolreprod.103.019745

21. Ábrahám IM, Han S-K, Todman MG, Korach KS, Herbison AE. Estrogen Receptor $\beta$ Mediates Rapid Estrogen Actions on Gonadotropin-Releasing Hormone Neurons In Vivo. J Neurosci (2003) 23(13):5771-7. doi: 10.1523/ JNEUROSCI.23-13-05771.2003

22. Kriegsfeld LJ, Mei DF, Bentley GE, Ubuka T, Mason AO, Inoue K, et al. Identification and Characterization of a Gonadotropin-Inhibitory System in the Brains of Mammals. Proc Natl Acad Sci USA (2006) 103:2410-5. doi: 10.1073/pnas.0511003103

23. Soga T, Kitahashi T, Clarke IJ, Parhar IS. Gonadotropin-Inhibitory Hormone Promoter-Driven Enhanced Green Fluorescent Protein Expression Decreases During Aging in Female Rats. Endocrinology (2014) 155:1944-55. doi: 10.1210/en.2013-1786

24. Gojska NM, Belsham DD. Glucocorticoid Receptor-Mediated Regulation of Rfrp (GnIH) and Gpr147 (GnIH-R) Synthesis in Immortalized Hypothalamic Neurons. Mol Cell Endocrinol (2014) 384:23-1. doi: 10.1016/j.mce.2013.12.015

25. Son YL, Ubuka T, Narihiro M, Fukuda Y, Hasunuma I, Yamamoto K, et al. Molecular Basis for the Activation of Gonadotropin-Inhibitory Hormone Gene Transcription by Corticosterone. Endocrinology (2012) 155(5):1817-26. doi: 10.1210/en.2013-2076

26. Boden MJ, Kennaway DJ. Circadian Rhythms and Reproduction. Reproduction (2006) 132(3):379-92. doi: 10.1530/rep.1.00614

27. Goldman BD. The Circadian Timing System and Reproduction in Mammals. Steroids (1999) 64(9):679-85. doi: 10.1016/S0039-128X(99)00052-5

28. Peterlin A, Kunej T, Peterlin B. The Role of Circadian Rhythm in Male Reproduction. Curr Opin Endocrinol Diabetes Obes (2019) 26(6):313-6. doi: 10.1097/MED.0000000000000512

29. Zhang W-X, Chen S-Y, Liu C. Regulation of Reproduction by the Circadian Rhythms. Sheng Li Xue Bao:[Acta Physiol Sinica] (2016) 68(6):799-808. doi: 10.13294/j.aps.2016.0089

30. Kennaway DJ. The Role of Circadian Rhythmicity in Reproduction. Hum Reprod Update (2005) 11(1):91-101. doi: 10.1093/humupd/dmh054

31. Turek FW, Swann J, Earnest DJ. Role of the Circadian System in Reproductive Phenomena. Recent Prog Horm Res (1984) 40:143-83. doi: 10.1016/b978-0-12-571140-1.50009-8

32. Tsutsui K, Ukena K. Hypothalamic LPXRF-Amide Peptides in Vertebrates: Identification, Localization and Hypophysiotropic Activity. Peptides (2006) 27(5):1121-9. doi: 10.1016/j.peptides.2005.06.036

33. Tsutsui K, Osugi T, Son YL, Ubuka T. Structure, Function and Evolution of GnIH. Gen Comp Endocrinol (2018) 264:48-57. doi: 10.1016/j.ygcen. 2017.07.024

34. Ogawa S, Parhar I. Structural and Functional Divergence of GonadotropinInhibitory Hormone (GnIH) From Jawless Fish to Mammals. Front Endocrinol (2014) 5:177. doi: 10.3389/fendo.2014.00177

35. Amano M, Moriyama S, Iigo M, Kitamura S, Amiya N, Yamamori K, et al. Novel Fish Hypothalamic Neuropeptides Stimulate the Release of Gonadotrophins and Growth Hormone From the Pituitary of Sockeye Salmon. J Endocrinol (2006) 188(3):417-23. doi: 10.1677/joe.1.06494

36. Biswas S, Jadhao AG, Pinelli C, Palande NV, Tsutsui K. GnIH and GnRH Expressions in the Central Nervous System and Pituitary of Indian Major Carp, Labeo Rohita During Ontogeny: An Immunocytochemical Study. Gen Comp Endocrinol (2015) 220:88-92. doi: 10.1016/j.ygcen. 2014.06.005

37. Biran J, Golan M, Mizrahi N, Ogawa S, Parhar IS, Levavi-Sivan B. LPXRFa, the Piscine Ortholog of GnIH, and LPXRF Receptor Positively Regulate Gonadotropin Secretion in Tilapia (Oreochromis Niloticus). Endocrinology (2014) 155(11):4391-401. doi: 10.1210/en.2013-2047

38. Osugi T, Ukena K, Bentley GE, O'Brien S, Moore IT, Wingfield JC, et al. Gonadotropin-Inhibitory Hormone in Gambel's White-Crowned Sparrow (Zonotrichia Leucophrys Gambelii): cDNA Identification, Transcript 
Localization and Functional Effects in Laboratory and Field Experiments. J Endocrinol (2004) 182(1):33-42. doi: 10.1677/joe.0.1820033

39. Johnson MA, Tsutsui K, Fraley GS. Rat RFamide-Related Peptide-3 Stimulates GH Secretion, Inhibits LH Secretion, and Has Variable Effects on Sex Behavior in the Adult Male Rat. Hormones Behav (2007) 51(1):17180. doi: 10.1016/j.yhbeh.2006.09.009

40. Bentley GE, Kriegsfeld LJ, Osugi T, Ukena K, O'brien S, Perfito N, et al. Interactions of Gonadotropin-Releasing Hormone $(\mathrm{GnRH})$ and Gonadotropin-Inhibitory Hormone (GnIH) in Birds and Mammals. J Exp Zool Part A: Comp Exp Biol (2006) 305A(9):807-14. doi: 10.1002/jez.a.306

41. Yin H, Ukena K, Ubuka T, Tsutsui K. A Novel G Protein-Coupled Receptor for Gonadotropin-Inhibitory Hormone in the Japanese Quail (Coturnix Japonica): Identification, Expression and Binding Activity. J Endocrinol (2005) 184:10. doi: 10.1677/joe.1.05926

42. Geraghty AC, Muroy SE, Zhao S, Bentley GE, Kriegsfeld LJ, Kaufer D. Knockdown of Hypothalamic RFRP3 Prevents Chronic Stress-Induced Infertility and Embryo Resorption. Elife (2015) 4:e04316. doi: 10.7554/ eLife.04316

43. Ubuka T, Son YL, Bentley GE, Millar RP, Tsutsui K. GonadotropinInhibitory Hormone (GnIH), GnIH Receptor and Cell Signaling. Gen Comp Endocrinol (2013) 190:10-7. doi: 10.1016/j.ygcen.2013.02.030

44. Peters J. Gene Regulation in the Hypothalamic-Pituitary-Gonadal Axis of the Green Anole Lizard (Anolis Carolinensis). Minnesota (MN): Minnesota State University, Mankato (2018).

45. Bonini JA, Jones KA, Adham N, Forray C, Artymyshyn R, Durkin MM, et al. Identification and Characterization of Two G Protein-Coupled Receptors for Neuropeptide Ff. J Biochem Chem (2000) 275:8. doi: 10.1074/ jbc.M004385200

46. Ubuka T, Tsutsui K. Evolution of Gonadotropin-Inhibitory Hormone Receptor and Its Ligand. Gen Comp Endocrinol (2014) 209:14. doi: 10.1016/j.ygcen.2014.09.002

47. Liu Q, Guan X-M, Martin WJ, McDonald TP, Clements MK, Jiang Q, et al. Identification and Characterization of Novel Mammalian Neuropeptide FF-Like Peptides That Attenuate Morphine-Induced Antinociception. J Biochem Chem (2001) 276(5):9. doi: 10.1074/jbc. M105308200

48. Gouarderes C, Mazarguil H, Mollereau C, Chartrel N, Leprince J, Vaudry H, et al. Functional Differences Between $\mathrm{NPFF}_{1}$ and $\mathrm{NPFF}_{2}$ Receptor Coupling: High Intrinsic Activities of RFamide-Related Peptides on Stimulation of $\left[{ }^{35}\right.$ S]GTP $\psi$ S Binding. Neuropharmacology (2007) 52:11. doi: 10.1016/ j.neuropharm.2006.07.034

49. Mollereau C, Mazarguil H, Marcus D, Quelven I, Kotani M, Lannoy V, et al. Pharmacological Characterization of Human $\mathrm{NPFF}_{1}$ and $\mathrm{NPFF}_{2}$ Receptors Expressed in CHO Cells by Using NPY $\mathrm{Y}_{1}$ Receptor Antagonists. Eur J Pharmacol (2002) 451:12. doi: 10.1016/S0014-2999(02)02224-0

50. Iwasa T, Matsuzaki T, Murakami M, Kinouchi R, Osugi T, Gereltsetseg G, et al. Developmental Changes in the Mammalian Gonadotropin-Inhibitory Hormone (GnIH) Ortholog RFamide-Related Peptide (RFRP) and Its Cognate Receptor GPR147 in the Rat Hypothalamus. Int J Dev Neurosci (2012) 30(1):31-7. doi: 10.1016/j.ijdevneu.2011.10.003

51. Rizwan MZ, Poling MC, Corr M, Cornes PA, Augustine RA, Quennell JH, et al. RFamide-Related Peptide-3 Receptor Gene Expression in GnRH and Kisspeptin Neurons and GnRH-Dependent Mechanism of Action. Endocrinology (2012) 153(8):3770-9. doi: 10.1210/en.2012-1133

52. Yang HYT, Iadarola MJ. Activation of Spinal Neuropeptide FF and the Neuropeptide FF Receptor 2 During Inflammatory Hyperalgesia in Rats. Neuroscience (2003) 118(1):179-87. doi: 10.1016/S0306-4522(02)00931-4

53. Jadhao AG, Pinelli C, D'Aniello B, Tsutsui K. Gonadotropin-Inhibitory Hormone $(\mathrm{GnIH})$ in the Amphibian Brain and its Relationship With the Gonadotropin Releasing Hormone (GnRH) System: An Overview. Gen Comp Endocrinol (2017) 240:69-76. doi: 10.1016/j.ygcen.2016.09.006

54. Zhao S, Zhu E, Yang C, Bentley GE, Tsutsui K, Kriegsfeld LJ. RFamideRelated Peptide and Messenger Ribonucleic Acid Expression in Mammalian Testis: Association With the Spermatogenic Cycle. Endocrinology (2010) 151 (2):617-27. doi: 10.1210/en.2009-0978

55. Oishi H, Klausen C, Bentley GE, Osugi T, Tsutsui K, Gilks CB, et al. The Human Gonadotropin-Inhibitory Hormone Ortholog RFamide-Related Peptide-3 Suppresses Gonadotropin-Induced Progesterone Production in
Human Granulosa Cells. Endocrinology (2012) 153(7):3435-45. doi: 10.1210/en.2012-1066

56. Ikemoto T, Park MK. Chicken RFamide-Related Peptide (GnIH) and Two Distinct Receptor Subtypes: Identification, Molecular Characterization, and Evolutionary Considerations. J Reprod Dev (2005) 51(3):359-77. doi: $10.1262 /$ jrd. 16087

57. Shimizu M, Bédécarrats GY. Activation of the Chicken GonadotropinInhibitory Hormone Receptor Reduces Gonadotropin Releasing Hormone Receptor Signaling. Gen Comp Endocrinol (2010) 167(2):331-7. doi: 10.1016/j.ygcen.2010.03.029

58. Son YL, Ubuka T, Millar RP, Kanasaki H, Tsutsui K. GonadotropinInhibitory Hormone Inhibits GnRH-Induced Gonadotropin Subunit Gene Transcriptions by Inhibiting AC/cAMP/PKA-Dependent ERK Pathway in L $\beta$ t2 Cells. Endocrinology (2012) 153(5):2332-43. doi: 10.1210/en.2011-1904

59. Son YL, Ubuka T, Soga T, Yamamoto K, Bentley GE, Tsutsui K. Inhibitory Action of Gonadotropin-Inhibitory Hormone on the Signaling Pathways Induced by Kisspeptin and Vasoactive Intestinal Polypeptide in GnRH Neuronal Cell Line, GT1-7. FASEB J (2016) 30(6):2198-210. doi: 10.1096/ fj.201500055

60. Stojilkovic SS, Tomic M, Kukuljan M, Catt KJ. Control of Calcium Spiking Frequency in Pituitary Gonadotrophs by a Single-Pool Cytoplasmic Oscillator. Mol Pharmacol (1994) 45(5):1013-21.

61. Naor Z. Signal Transduction Mechanisms of Ca2+ Mobilizing Hormones: The Case of Gonadotropin-Releasing Hormone. Endocrine Rev (1990) 11 (2):326-53. doi: 10.1210/edrv-11-2-326

62. Fang Q, Jiang T-N, Li N, Han Z-1, Wang R. Central Administration of Neuropeptide FF and Related Peptides Attenuate Systemic Morphine Analgesia in Mice. Protein Pept Lett (2011) 18(4):403-9. doi: 10.2174/ 092986611794654012

63. Madelaine R, Lovett-Barron M, Halluin C, Andalman AS, Liang J, Skariah GM, et al. The Hypothalamic NPVF Circuit Modulates Ventral Raphe Activity During Nociception. Sci Rep (2017) 7(1):41528. doi: 10.1038/ srep41528

64. Lénárd L, Kovács A, Ollmann T, Péczely L, Zagoracz O, Gálosi R, et al. Positive Reinforcing Effects of RFamide-Related Peptide-1 in the Rat Central Nucleus of Amygdala. Behav Brain Res (2014) 275:101-6. doi: 10.1016/ j.bbr.2014.08.051

65. Nichols R, Demers LA, Larsen BM, Robinson D, Converso K, Russell MW, et al. Human RFamide-Related Peptide-1 Diminishes Cellular and Integrated Cardiac Contractile Performance. Peptides (2010) 31(11):206774. doi: 10.1016/j.peptides.2010.07.012

66. Bentley GE, Tsutsui K, Kriegsfeld LJ. Recent Studies of GonadotropinInhibitory Hormone (GnIH) in the Mammalian Hypothalamus, Pituitary and Gonads. Brain Res (2010) 1364:62-71. doi: 10.1016/j.brainres. 2010.10.001

67. Paullada-Salmerón JA, Cowan M, Aliaga-Guerrero M, Morano F, Zanuy S, Muñoz-Cueto JA. Gonadotropin Inhibitory Hormone Down-Regulates the Brain-Pituitary Reproductive Axis of Male European Sea Bass (Dicentrarchus Labrax)1. Biol Reprod (2016) 94(6):121-30. doi: 10.1095/ biolreprod.116.139022

68. Moussavi M, Wlasichuk M, Chang JP, Habibi HR. Seasonal Effect of GnIH on Gonadotrope Functions in the Pituitary of Goldfish. Mol Cell Endocrinol (2012) 350(1):53-60. doi: 10.1016/j.mce.2011.11.020

69. Bentley GE, Jensen JP, Kaur GJ, Wacker DW, Tsutsui K, Wingfield JC. Rapid Inhibition of Female Sexual Behavior by Gonadotropin-Inhibitory Hormone (GnIH). Horm Behav (2006) 49:6. doi: 10.1016/j.yhbeh.2005.12.005

70. Ubuka T, Ukena K, Sharp PJ, Bentley GE, Tsutsui K. GonadotropinInhibitory Hormone Inhibits Gonadal Development and Maintenance by Decreasing Gonadotropin Synthesis and Release in Male Quail. Endocrinology (2006) 147(3):1187-94. doi: 10.1210/en.2005-1178

71. Murakami M, Matsuzaki T, Iwasa T, Yasui T, Irahara M, Osugi T, et al. Hypophysiotropin Role of RFamide-Related Peptide-3 in the Inhibition of LH Secretion in Female Rats. J Endocrinol (2008) 199(1):8. doi: 10.1677/ JOE-08-0197

72. Anderson GM, Relf HL, Rizwan MZ, Evans JJ. Central and Peripheral Effects of RFamide-Related Peptide-3 on Luteinizing Hormone and Prolactin Secretion in Rats. Endocrinology (2009) 150(4):1834-40. doi: 10.1210/ en.2008-1359 
73. Pineda R, Garcia-Galiano D, Sanchez-Garrido MA, Romero M, Ruiz-Pino F, Aguilar E, et al. Characterization of the Inhibitory Roles of RFRP3, the Mammalian Ortholog of GnIH, in the Control of Gonadotropin Secretion in the Rat: In Vivo and In Vitro Studies. Am J Physiol-Endocrinol Metab (2010) 299(1):E39-46. doi: 10.1152/ajpendo.00108.2010

74. Xiang W, Zhang B, Lv F, Ma Y, Chen H, Chen L, et al. The Inhibitory Effects of RFamide-Related Peptide 3 on Luteinizing Hormone Release Involves an Estradiol-Dependent Manner in Prepubertal But Not in Adult Female Mice. Biol Reprod (2015) 93(2):30. doi: 10.1095/biolreprod.115.128777

75. Ancel C, Inglis MA, Anderson GM. Central RFRP-3 Stimulates LH Secretion in Male Mice and Has Cycle Stage-Dependent Inhibitory Effects in Females. Endocrinology (2017) 158(9):2873-83. doi: 10.1210/en.2016-1902

76. Kadokawa H, Shibata M, Tanaka Y, Kojima T, Matsumoto K, Oshima K, et al. Bovine C-Terminal Octapeptide of RFamide-Related Peptide-3 Suppresses Lutenizing Hormone (LH) Secretion From the Pituitary as Well as Pulsatile LH Secretion in Bovines. Domest Anim Endocrinol (2009) 36(4):6. doi: 10.1016/j.domaniend.2009.02.001

77. Ancel C, Bentsen AH, Sébert M-E, Tena-Sempere M, Mikkelsen JD, Simonneaux V. Stimulatory Effect of RFRP-3 on the Gonadotrophic Axis in the Male Syrian Hamster: The Exception Proves the Rule. Endocrinology (2012) 153(3):11. doi: 10.1210/en.2011-1622

78. Wickstrom M, Dyberg C, Milosevic J, Einvik C, Calero R, Sveinbjornsson B, et al. Wnt/B-Catenin Pathway Regulates MGMT Gene Expression in Cancer and Inhibition of Wnt Signalling Prevents Chemoresistance. Nat Commun (2015) 6:10. doi: 10.1038/ncomms9904

79. Henningsen JB, Ancel C, Mikkelsen JD, Gauer F, Simonneaux V. Roles of RFRP-3 in the Daily and Seasonal Regulation of Reproductive Activity in Female Syrian Hamsters. Endocrinology (2016) 158(3):652-63. doi: 10.1210/ en.2016-1689

80. Clarke IJ, Smith JT, Henry BA, Oldfield BJ, Stefanidis A, Millar RP, et al. Gonadotropin-Inhibitory Hormone Is a Hypothalamic Peptide That Provides a Molecular Switch Between Reproduction and Feeding. Neuroendocrinology (2012) 95:12. doi: 10.1159/000332822

81. Decourt C, Anger K, Robert V, Lomet D, Bartzen-Sprauer J, Caraty A, et al. No Evidence That RFamide-Related Peptide 3 Directly Modulates LH Secretion in the Ewe. Endocrinology (2016) 157(4):1566-75. doi: 10.1210/ en.2015-1854

82. Thorson JF, Prezotto LD, Cardoso RC, Sharpton SM, Edwards JF, Welsh TH Jr, et al. Hypothalamic Distribution, Adenohypophyseal Receptor Expression, and Ligand Functionality of RFamide-Related Peptide 3 in the Mare During the Breeding and Nonbreeding Seasons1. Biol Reprod (2014) 90(2):28-36. doi: 10.1095/biolreprod.113.112185

83. George JT, Hendrikse M, Veldhuis JD, Clarke IJ, Anderson RA, Millar RP. Effect of Gonadotropin-Inhibitory Hormone on Luteinizing Hormone Secretion in Humans. Clin Endocrinol (Oxf) (2017) 86(5):731-8. doi: $10.1111 /$ cen. 13308

84. Jørgensen SR, Andersen MD, Overgaard A, Mikkelsen JD. Changes in RFamide-Related Peptide-1 (RFRP-1)-Immunoreactivity During Postnatal Development and the Estrous Cycle. Endocrinology (2014) 155(11):4402-10. doi: $10.1210 /$ en.2014-1274

85. Dave A, Krishna A, Tsutsui K. Direct Effects of RFRP-1, a Mammalian GnIH Ortholog, on Ovarian Activities of the Cyclic Mouse. Gen Comp Endocrinol (2017) 252:193-9. doi: 10.1016/j.ygcen.2017.06.024

86. Ando H, Shahjahan M, Kitahashi T. Periodic Regulation of Expression of Genes for Kisspeptin, Gonadotropin-Inhibitory Hormone and Their Receptors in the Grass Puffer: Implications in Seasonal, Daily and Lunar Rhythms of Reproduction. Gen Comp Endocrinol (2018) 265:149-53. doi: 10.1016/j.ygcen.2018.04.006

87. Choi CY, Shin HS, Kim NN, Yang S-G, Kim B-S, Yu YM. Time-Related Effects of Various LED Light Spectra on Reproductive Hormones in the Brain of the Goldfish Carassius Auratus. Biol Rhythm Res (2015) 46(5):67182. doi: 10.1080/09291016.2015.1046247

88. Paullada-Salmerón JA, Loentgen GH, Cowan M, Aliaga-Guerrero M, del Carmen Rendón-Unceta M, Muñoz-Cueto JA. Developmental Changes and Day-Night Expression of the Gonadotropin-Inhibitory Hormone System in the European Sea Bass: Effects of Rearing Temperature. Comp Biochem Physiol Part A: Mol Integr Physiol (2017) 206:54-62. doi: 10.1016/ j.cbpa.2017.01.009
89. Choi YJ, Kim NN, Habibi HR, Choi CY. Effects of Gonadotropin Inhibitory Hormone or Gonadotropin-Releasing Hormone on Reproduction-Related Genes in the Protandrous Cinnamon Clownfish, Amphiprion Melanopus. Gen Comp Endocrinol (2016) 235:89-99. doi: 10.1016/j.ygcen.2016.06.010

90. Dixit AS, Singh NS, Byrsat S. Role of GnIH in Photoperiodic Regulation of Seasonal Reproduction in the Eurasian Tree Sparrow. J Exp Biol (2017) 220 (20):3742-50. doi: 10.1242/jeb.164541

91. Dixit AS, Byrsat S, Singh NS. Circadian Rhythm in Photoperiodic Expressions of GnRH-I and GnIH Regulating Seasonal Reproduction in the Eurasian Tree Sparrow, Passer Montanus. J Photochem Photobiol B: Biol (2020) 211:111993. doi: 10.1016/j.jphotobiol.2020.111993

92. Mason AO, Duffy S, Zhao S, Ubuka T, Bentley GE, Tsutsui K, et al. Photoperiod and Reproductive Condition are Associated With Changes in RFamide-Related Peptide (RFRP) Expression in Syrian Hamsters (Mesocricetus Auratus). J Biol Rhythms (2010) 25:176 - 85. doi: 10.1177/ 0748730410368821

93. Maywood ES, Bittman EL, Hastings MH. Lesions of the Melatonin- and Androgen-Responsive Tissue of the Dorsomedial Nucleus of the Hypothalamus Block the Gonadal Response of Male Syrian Hamsters to Programmed Infusions of Melatonin1. Biol Reprod (1996) 54(2):470-7. doi: 10.1095/biolreprod54.2.470

94. Bartness TJ, Goldman BD, Bittman EL. SCN Lesions Block Responses to Systemic Melatonin Infusions in Siberian Hamsters. Am J Physiol-Regulatory Integr Comp Physiol (1991) 260(1):R102-R12. doi: 10.1152/ajpregu. 1991.260.1.R102

95. Ubuka T, Inoue K, Fukuda Y, Mizuno T, Ukena K, Kriegsfeld LJ, et al. Identification, Expression, and Physiological Functions of Siberian Hamster Gonadotropin-Inhibitory Hormone. Endocrinology (2012) 153(373385):373-85. doi: 10.1210/en.2011-1110

96. Revel FG, Saboureau M, Pévet P, Simonneaux V, Mikkelsen JD. RFamideRelated Peptide Gene is a Melatonin-Driven Photoperiodic Gene. Endocrinology (2008) 149(3):902-12. doi: 10.1210/en.2007-0848

97. Dardente H, Birnie M, Lincoln G, Hazlerigg D. RFamide-Related Peptide and its Cognate Receptor in the Sheep: cDNA Cloning, mRNA Distribution in the Hypothalamus and the Effect of Photoperiod. J Neuroendocrinol (2008) 20(11):1252-9. doi: 10.1111/j.1365-2826.2008.01784.x

98. Jafarzadeh Shirazi M, Zamiri M, Salehi M, Moradi S, Tamadon A, Namavar M, et al. Differential Expression of RF Amide-Related Peptide, a Mammalian Gonadotrophin-Inhibitory Hormone Orthologue, and Kisspeptin in the Hypothalamus of Abadeh Ecotype Does During Breeding and Anoestrous Seasons. J Neuroendocrinol (2014) 26(3):186-94. doi: 10.1111/jne.12137

99. Fraley GS, Coombs E, Gerometta E, Colton S, Sharp PJ, Li Q, et al. Distribution and Sequence of Gonadotropin-Inhibitory Hormone and its Potential Role as a Molecular Link Between Feeding and Reproductive Systems in the Pekin Duck (Anas Platyrhynchos Domestica). Gen Comp Endocrinol (2013) 184:8. doi: 10.1016/j.ygcen.2012.11.026

100. Tachibana T, Sato M, Takahashi H, Ukena K, Tsutsui K, Furuse M. Gonadotropin-Inhibiting Hormone Stimulates Feeding Behaviour in Chicks. Brain Res (2005) 1050(1-2):7. doi: 10.1016/j.brainres.2005.05.035

101. Wisialowski T, Parker R, Preston E, Sainsbury A, Kraegen E, Herzog H, et al. Adrenalectomy Reduces Neuropeptide Y-Induced Insulin Release and NPY Receptor Expression in the Rat Ventromedial Hypothalamus. J Clin Invest (2000) 205(9):7. doi: 10.1172/JCI8695

102. McConn B, Wang G, Yi J, Gilbert ER, Osugi T, Ubuka T, et al. Gonadotropin-Inhibitory Hormone-Stimulation of Food Intake Is Mediated by Hypothalamic Effects in Chicks. Neuropeptides (2014) 48:8. doi: 10.1016/j.npep.2014.09.001

103. Surbhi, Rastogi A, Malik S, Rani S, Kumar V. Changes in Brain Peptides Associated With Reproduction and Energy Homeostasis in Photosensitive and Photorefractory Migratory Redheaded Buntings. Gen Comp Endocrinol (2016) 230-231:67-75. doi: 10.1016/j.ygcen.2016.03.031

104. Rastogi A, Rani S, Kumar V. Seasonal Plasticity in the Peptide Neuronal Systems: Potential Roles of Gonadotrophin-Releasing Hormone, Gonadotrophin-Inhibiting Hormone, Neuropeptide Y and Vasoactive Intestinal Peptide in the Regulation of the Reproductive Axis in Subtropical Indian Weaver Birds. J Neuroendocrinol (2015) 27(5):357-69. doi: $10.1111 /$ jne.12274 
105. Davies S, Cros T, Richard D, Meddle SL, Tsutsui K, Deviche P. Food Availability, Energetic Constraints and Reproductive Development in a Wild Seasonally Breeding Songbird. Funct Ecol (2015) 29(11):1421-34. doi: 10.1111/1365-2435.12448

106. Newmyer BA, Cline MA. Neuropeptide SF is Associated With Reduced Food Intake in Chicks. Behav Brain Res (2009) 205(1):311-4. doi: 10.1016/ j.bbr.2009.06.013

107. Kovács A, László K, Gálosi R, Tóth K, Ollmann T, Péczely L, et al. Microinjection of RFRP-1 in the Central Nucleus of Amygdala Decreases Food Intake in the Rat. Brain Res Bull (2012) 88(6):589-95. doi: 10.1016/ j.brainresbull.2012.06.001

108. Thomas FSK, Higuchi Y, Ogawa S, Soga T, Parhar IS. Acute Social Defeat Stress Upregulates Gonadotrophin Inhibitory Hormone and its Receptor But Not Corticotropin-Releasing Hormone and ACTH in the Male Nile Tilapia (Oreochromis Niloticus). Peptides (2021) 138:170504. doi: 10.1016/ j.peptides.2021.170504

109. Tsutsui K, Ubuka T, Bentley GE, Kriegsfeld LJ. Review: Regulatory Mechanisms of Gonadotropin-Inhibitory Hormone (GnIH) Synthesis and Release in Photoperiodic Animals. Front Neurosci (2013) 7:60. doi: 10.3389/ fnins. 2013.00060

110. Tsutsui K, Ubuka T. How to Contribute to the Progress of Neuroendocrinology: Discovery of GnIH and Progress of GnIH Research. Front Endocrinol (2018) 9:16. doi: 10.3389/fendo.2018.00662

111. Ubuka T, Mukai M, Wolfe J, Beverly R, Clegg S, Wang A, et al. RNA Interference of Gonadotropin-Inhibitory Hormone Gene Induces Arousal in Songbirds. PloS One (2012) 7(1):e30202-e. doi: 10.1371/journal.pone.0030202

112. Piekarski DJ, Zhao S, Jennings KJ, Iwasa T, Legan SJ, Mikkelsen JD, et al. Gonadotropin-Inhibitory Hormone Reduces Sexual Motivation But Not Lordosis Behavior in Female Syrian Hamsters (Mesocricetus Auratus). Horm Behav (2013) 64:10. doi: 10.1016/j.yhbeh.2013.06.006

113. Ubuka T, Haraguchi S, Tobari Y, Narihiro M, Ishikawa K, Hayashi T, et al. Hypothalamic Inhibition of Socio-Sexual Behaviour by Increasing Neuroestrogen Synthesis. Nat Commun (2013) 5:14. doi: 10.1038/ncomms4061

114. Jennings KJ, Chang J, Cho H, Piekarski DJ, Russo KA, Kriegsfeld LJ. Aggressive Interactions Are Associated With Reductions in RFamideRelated Peptide, But Not Kisspeptin, Neuronal Activation in Mice. Horm Behav (2016) 78:127-34. doi: 10.1016/j.yhbeh.2015.10.021

115. Abdel-Aleem GA, Shafik NM, El-Magd MA, Mohamed DA. Soya Bean Rich Diet is Associated With Adult Male Rat Aggressive Behavior: Relation to RF Amide-Related Peptide 3-Aromatase-Neuroestrogen Pathway in the Brain. Metab Brain Dis (2019) 34(4):1103-15. doi: 10.1007/s11011-019-00431-2

116. Duval F, Mokrani M-C, Monreal J, Weiss T, Fattah S, Hamel B, et al. Interaction Between the Serotonergic System and HPA and HPT Axes in Patients With Major Depression: Implications for Pathogenesis of Suicidal Behavior. Dialogues Clin Neurosci (2002) 4(4):417-. doi: 10.31887/ DCNS.2002.4.4/fduval

117. Kirby ED, Geraghty AC, Ubuka T, Bentley GE, Kaufer D. Stress Increases Putative Gonadotropin Inhibitory Hormone and Decreases Luteinizing Hormone in Male Rats. Proc Natl Acad Sci (2009) 106(27):11324-9. doi: 10.1073/pnas.0901176106

118. Choi YJ, Habibi HR, Kil G-S, Jung M-M, Choi CY. Effect of Cortisol on Gonadotropin Inhibitory Hormone $(\mathrm{GnIH})$ in the Cinnamon Clownfish, Amphiprion Melanopus. Biochem Biophys Res Commun (2017) 485(2):3428. doi: 10.1016/j.bbrc.2017.02.078

119. Calisi RM, Rizzo NO, Bentley GE. Seasonal Differences in Hypothalamic EGR-1 and GnIH Expression Following Capture-Handling Stress in House Sparrows (Passer Domesticus). Gen Comp Endocrinol (2008) 157(3):283-7. doi: 10.1016/j.ygcen.2008.05.010
120. Kaewwongse M, Takayanagi Y, Onaka T. Effects of RFamide-Related Peptide (RFRP)-1 and RFRP-3 on Oxytocin Release and Anxiety-Related Behaviour in Rats. Neuroendocrinology (2011) 23:20-7. doi: 10.1111/j.13652826.2010.02077.x

121. Tanaka M, Telegdy G. Antidepressant-Like Effects of Neuropeptide SF (NPSF). ArXiv Prepr ArXiv (2020) 200513256.

122. Soga T, Wong DW, Clarke IJ, Parhar IS. Citalopram (Antidepressant) Administration Causes Sexual Dysfunction in Male Mice Through RFAmide Related Peptide in the Dorsomedial Hypothalamus. Neuropharmacology (2010) 59(1):77-85. doi: 10.1016/j.neuropharm. 2010.03.018

123. Soga T, Dalpatadu SL, Wong DW, Parhar IS. Neonatal Dexamethasone Exposure Down-Regulates GnRH Expression Through the GnIH Pathway in Female Mice. Neuroscience (2012) 218(56-64):56-64. doi: 10.1016/ j.neuroscience.2012.05.023

124. Teo CH, Soga T, Parhar IS. Social Isolation Modulates CLOCK Protein and Beta-Catenin Expression Pattern in Gonadotropin-Inhibitory Hormone Neurons in Male Rats. Front Endocrinol (2017) 8:225. doi: 10.3389/ fendo.2017.00225

125. Teo CH, Soga T, Parhar I. Lithium Chloride Enhances Serotonin Induced Calcium Activity in EGFP-GnIH Neurons. Sci Rep (2020) 10(1):1-7. doi: 10.1038/s41598-020-70710-x

126. Kang DW, Lee S-H, Yoon JW, Park W-S, Choi K-Y. Phospholipase D1 Drives a Positive Feedback Loop to Reinforce the Wnt/B-Catenin/TCF Signaling Axis. Cancer Res (2010) 70(10):4233-42. doi: 10.1158/00085472.CAN-09-3470

127. Lopez CI, Pelletán LE, Suhaiman L, De Blas GA, Vitale N, Mayorga LS, et al. Diacylglycerol Stimulates Acrosomal Exocytosis by Feeding Into a PKC- and PLD1-Dependent Positive Loop That Continuously Supplies Phosphatidylinositol 4,5-Bisphosphate. Biochim Biophys Acta (BBA) Mol Cell Biol Lipids (2012) 1821(9):1186-99. doi: 10.1016/j.bbalip.2012.05.001

128. Cheng H, Grodnitzky JA, Yibchok-anun S, Ding J, Hsu WH. Somatostatin Increases Phospholipase D Activity and Phosphatidylinositol 4,5Bisphosphate Synthesis in Clonal $\beta$ Cells HIT-T15. Mol Pharmacol (2005) 67(6):2162. doi: 10.1124/mol.104.010470

129. Lee DA, Andreev A, Truong TV, Chen A, Hill AJ, Oikonomou G, et al. Genetic and Neuronal Regulation of Sleep by Neuropeptide VF. Elife (2017) 6:e25727. doi: 10.7554/eLife.25727

130. Lee DA, Oikonomou G, Cammidge T, Andreev A, Hong Y, Hurley H, et al. Neuropeptide VF Neurons Promote Sleep via the Serotonergic Raphe. Elife (2020) 9:e54491. doi: 10.7554/eLife.54491

Conflict of Interest: The authors declare that the research was conducted in the absence of any commercial or financial relationships that could be construed as a potential conflict of interest.

Publisher's Note: All claims expressed in this article are solely those of the authors and do not necessarily represent those of their affiliated organizations, or those of the publisher, the editors and the reviewers. Any product that may be evaluated in this article, or claim that may be made by its manufacturer, is not guaranteed or endorsed by the publisher.

Copyright $\odot 2021$ Teo, Phon and Parhar. This is an open-access article distributed under the terms of the Creative Commons Attribution License (CC BY). The use, distribution or reproduction in other forums is permitted, provided the original author(s) and the copyright owner(s) are credited and that the original publication in this journal is cited, in accordance with accepted academic practice. No use, distribution or reproduction is permitted which does not comply with these terms. 